\title{
LEVEL II SCOUR ANALYSIS FOR BRIDGE 45a (BRIDUS00040045a) on U.S. ROUTE 4, crossing the OTTAUQUECHEE RIVER, BRIDGEWATER, VERMONT
}

U.S. Geological Survey Open-File Report 96-244

Prepared in cooperation with

VERMONT AGENCY OF TRANSPORTATION and

FEDERAL HIGHWAY ADMINISTRATION 


\section{LEVEL II SCOUR ANALYSIS FOR BRIDGE 45a (BRIDUS00040045a) on U.S. ROUTE 4, crossing the OTTAUQUECHEE RIVER, BRIDGEWATER, VERMONT \\ By SCOTT A. OLSON}

U.S. Geological Survey Open-File Report 96-244

Prepared in cooperation with

VERMONT AGENCY OF TRANSPORTATION and

FEDERAL HIGHWAY ADMINISTRATION 


\title{
U.S. DEPARTMENT OF THE INTERIOR BRUCE BABBITT, Secretary
}

\author{
U.S. GEOLOGICAL SURVEY \\ Gordon P. Eaton, Director
}

For additional information write to:

District Chief

U.S. Geological Survey 361 Commerce Way

Pembroke, NH 03275
Copies of this report may be purchased from:

U.S. Geological Survey Earth Science Information Center Open-File Reports Section Box 25286, MS 517 Federal Center

Denver, CO 80225 


\section{CONTENTS}

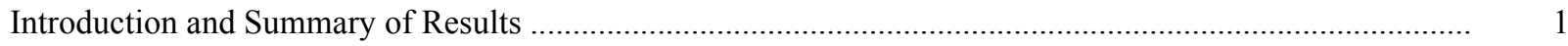



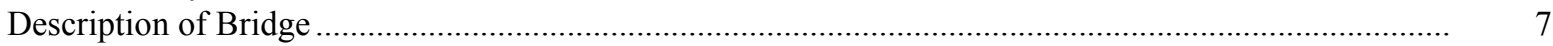

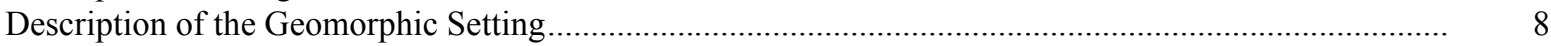

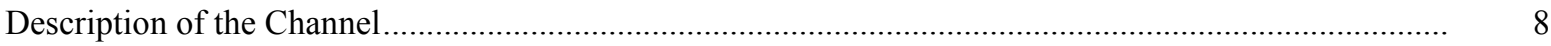

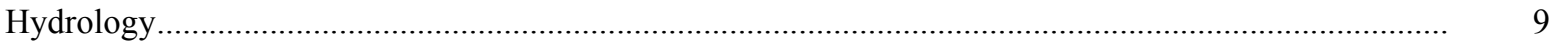

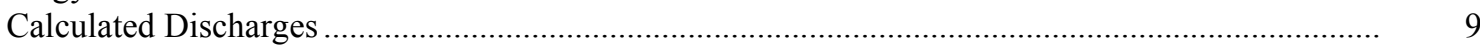

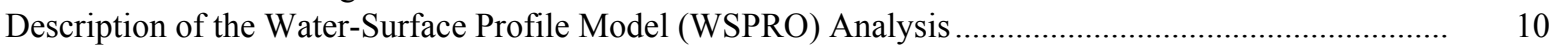

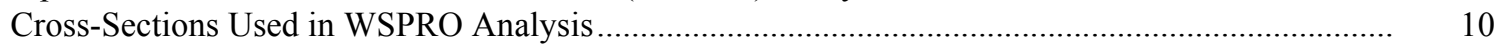

Data and Assumptions Used in WSPRO Model ...................................................................... 11

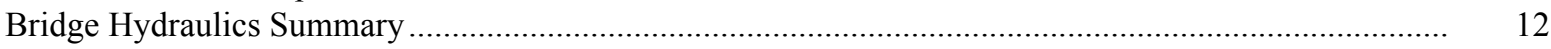

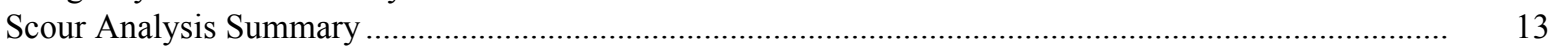

Special Conditions or Assumptions Made in Scour Analysis ...................................................... 13

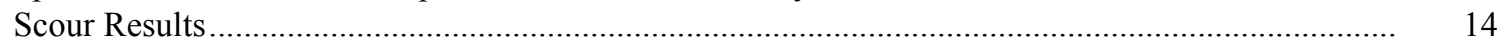

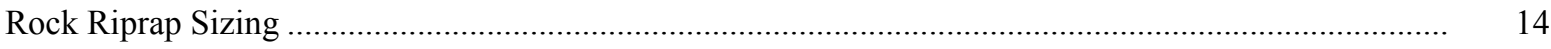

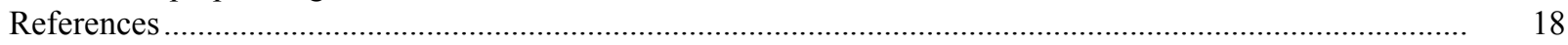

Appendixes:

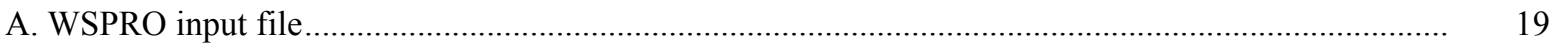

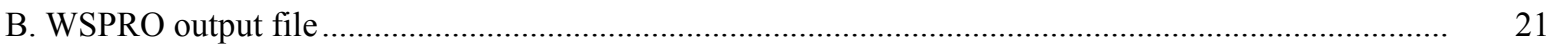

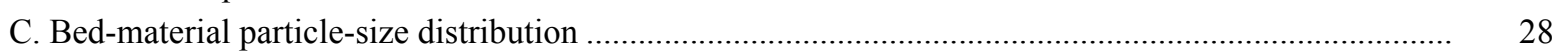

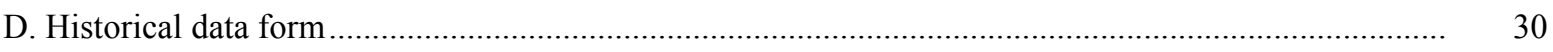

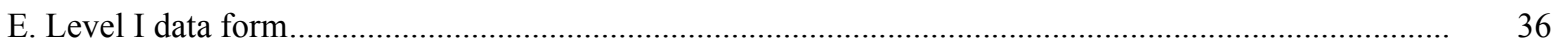

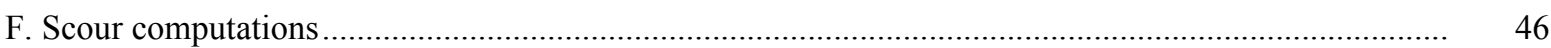

\section{FIGURES}

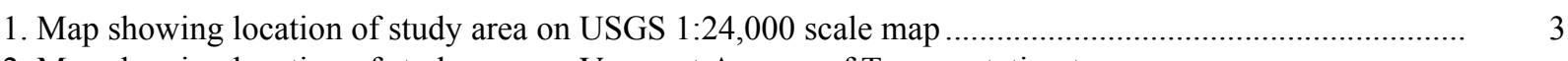

2. Map showing location of study area on Vermont Agency of Transportation town

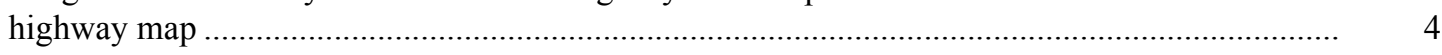

3. Structure BRIDUS00040045a viewed from upstream (October 26, 1994) ...............................................

4. Downstream channel viewed from structure BRIDUS00040045a (October 26, 1994). ......................... 5

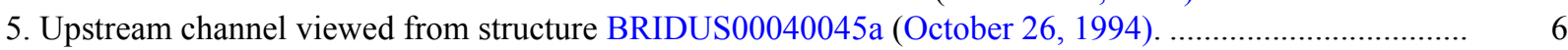

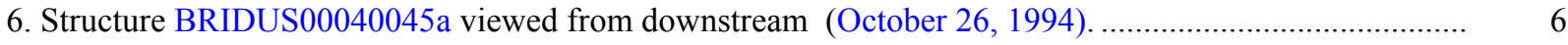

7. Water-surface profiles for the 100- and 500-year discharges at structure

BRIDUS00040045a on U.S. Route 4, crossing the the Ottauquechee River,

Bridgewater, Vermont.

8. Scour elevations for the 100- and 500-year discharges at structure

BRIDUS00040045a on U.S. Route 4, crossing the Ottauquechee River,

Bridgewater, Vermont.

\section{TABLES}

1. Remaining footing/pile depth at abutments for the 100-year discharge at structure BRIDUS00040045a on U.S. Route 4, crossing the Ottauquechee River,

Bridgewater, Vermont.

2. Remaining footing/pile depth at abutments for the 500-year discharge at structure

BRIDUS00040045a on U.S. Route 4, crossing the Ottauquechee River,

Bridgewater, Vermont.

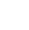

5

s

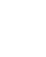

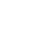




\begin{tabular}{|c|c|c|}
\hline Multiply & By & To obtain \\
\hline \multicolumn{3}{|c|}{ Length } \\
\hline inch (in.) & 25.4 & millimeter (mm) \\
\hline foot $(\mathrm{ft})$ & 0.3048 & meter $(\mathrm{m})$ \\
\hline mile (mi) & 1.609 & kilometer (km) \\
\hline \multicolumn{3}{|c|}{ Slope } \\
\hline foot per mile ( $\mathrm{ft} / \mathrm{mi})$ & 0.1894 & meter per kilometer $(\mathrm{m} / \mathrm{km})$ \\
\hline \multicolumn{3}{|c|}{ Area } \\
\hline square mile $\left(\mathrm{mi}^{2}\right)$ & 2.590 & square kilometer $\left(\mathrm{km}^{2}\right)$ \\
\hline \multicolumn{3}{|c|}{ Volume } \\
\hline cubic foot $\left(\mathrm{ft}^{3}\right)$ & $\begin{array}{l}0.02832 \\
\text { Velocity and Flow }\end{array}$ & cubic meter $\left(\mathrm{m}^{3}\right)$ \\
\hline foot per second (ft/s) & 0.3048 & meter per second $(\mathrm{m} / \mathrm{s})$ \\
\hline cubic foot per second $\left(\mathrm{ft}^{3} / \mathrm{s}\right)$ & 0.02832 & cubic meter per second $\left(\mathrm{m}^{3} / \mathrm{s}\right)$ \\
\hline $\begin{array}{l}\text { cubic foot per second per } \\
\text { square mile } \\
{\left[\left(\mathrm{ft}^{3} / \mathrm{s}\right) / \mathrm{mi}^{2}\right]}\end{array}$ & 0.01093 & $\begin{array}{l}\text { cubic meter per } \\
\text { second per square } \\
\text { kilometer }\left[\left(\mathrm{m}^{3} / \mathrm{s}\right) / \mathrm{km}^{2}\right]\end{array}$ \\
\hline
\end{tabular}

OTHER ABBREVIATIONS

$\begin{array}{lrlr}\mathrm{BF} & \text { bank full } & \text { LWW } & \text { left wingwall } \\ \mathrm{cfs} & \text { cubic feet per second } & \text { MC } & \text { main channel } \\ \mathrm{D}_{50} & \text { median diameter of bed material } & \text { RAB } & \text { right abutment } \\ \mathrm{DS} & \text { downstream } & \text { RABUT } & \text { face of right abutment } \\ \mathrm{elev} & \text { elevation } & \text { RB } & \text { right bank } \\ \mathrm{f} / \mathrm{p} & \text { flood plain } & \text { ROB } & \text { right overbank } \\ \mathrm{ft} & \text { square feet } & \text { RWW } & \text { right wingwall } \\ \mathrm{ft} / \mathrm{ft} & \text { feet per foot } & \text { TH } & \text { town highway } \\ \mathrm{JCT} & \text { junction } & \text { UB } & \text { under bridge } \\ \mathrm{LAB} & \text { left abutment } & \text { US } & \text { upstream } \\ \mathrm{LABUT} & \text { face of left abutment } & \text { USGS } & \text { United States Geological Survey } \\ \text { LB } & \text { left bank } & \text { VTAOT Vermont Agency of Transportation } \\ \text { LOB } & \text { left overbank } & \text { WSPRO } & \text { water-surface profile model }\end{array}$

In this report, the words "right" and "left" refer to directions that would be reported by an observer facing downstream. Sea level: In this report, "sea level" refers to the National Geodetic Vertical Datum of 1929-- a geodetic datum derived from a general adjustment of the first-order level nets of the United States and Canada, formerly called Sea Level Datum of 1929.

In the appendices, the above abbreviations may be combined. For example, USLB would represent upstream left bank. 


\title{
LEVEL II SCOUR ANALYSIS FOR BRIDGE 45a (BRIDUS00040045a) ON U.S. ROUTE 4, CROSSING THE OTTAUQUECHEE RIVER, BRIDGEWATER, VERMONT
}

\author{
By Scott A. Olson
}

\section{INTRODUCTION AND SUMMARY OF RESULTS}

This report provides the results of a detailed Level II analysis of scour potential at structure BRIDUS00040045a on U.S.. Route 4 crossing the Ottauquechee River, Bridgewater, Vermont (figures 1-8). A Level II study is a basic engineering analysis of the site, including a quantitative analysis of stream stability and scour (U.S. Department of Transportation, 1993). A Level I study is included in Appendix E of this report. A Level I study provides a qualitative geomorphic characterization of the study site. Information on the bridge available from VTAOT files was compiled prior to conducting Level I and Level II analyses and can be found in Appendix D.

The site is in the Green Mountain physiographic province of central Vermont in the town of Bridgewater. The $72.1-\mathrm{mi}^{2}$ drainage area is in a predominantly rural and forested basin. In the vicinity of the study site, the overbank areas are lawn or pasture with a few residences. The immediate channel banks have moderately dense woody vegetation.

In the study area, the Ottauquechee River has a sinuous channel with a slope of approximately $0.01 \mathrm{ft} / \mathrm{ft}$, an average channel top width of $81 \mathrm{ft}$ and an average channel depth of $3 \mathrm{ft}$. The predominant channel bed materials are gravel and cobble $\left(D_{50}\right.$ is $54.9 \mathrm{~mm}$ or $0.180 \mathrm{ft}$ ). The geomorphic assessment at the time of the Level I and Level II site visit on October 26, 1994, indicated that the reach was stable.

The U.S. Route 4 crossing of the Ottauquechee River is a 172-ft-long, two-lane bridge consisting of three steel-beam spans supported by spill-through abutments and two concrete piers (Vermont Agency of Transportation, written commun., August 25, 1994). The abutment and road approaches are protected by type- 2 stone fill (less than 36 inches diameter). The North Branch of the Ottauquechee River joins the Ottauquechee River approximately 200 feet upstream of the bridge on the main branch's left bank. The channel approach to the bridge has a mild bend with the bridge skewed 15 degrees to flow; the opening-skew-to-roadway is 30 degrees. Additional details describing conditions at the site are included in the Level II Summary, Appendix D, and Appendix E. 
Scour depths and rock rip-rap sizes were computed using the general guidelines described in Hydraulic Engineering Circular 18 (Richardson and others, 1993). Total scour at a highway crossing is comprised of three components: 1) long-term streambed degradation; 2) contraction scour (due to accelerated flow caused by a reduction in flow area at a bridge) and; 3) local scour (caused by accelerated flow around piers and abutments). Total scour is the sum of the three components. Equations are available to compute depths for contraction and local scour and a summary of the results of these computations follows.

Contraction scour for all modelled flows ranged from 3.1 to $4.0 \mathrm{ft}$. with the worst-case contraction scour occurring at the 500-year and incipient road-overflow discharges. Abutment scour ranged from 9.3 to $15.2 \mathrm{ft}$. The worst-case abutment scour also occurred at the 500-year discharge. Pier scour ranged from 11.4 to $12.4 \mathrm{ft}$. with the worst-case scenario occurring at the incipient roadway overflow discharge. The incipient roadway overflow discharge was between the 100- and 500-year discharges. Additional information on scour depths and depths to armoring are included in the section titled "Scour Results". Scouredstreambed elevations, based on the calculated scour depths, are presented in tables 1 and 2. A cross-section of the scour computed at the bridge is presented in figure 8. Scour depths were calculated assuming an infinite depth of erosive material and a homogeneous particlesize distribution.

It is generally accepted that the Froehlich equation (abutment scour) gives "excessively conservative estimates of scour depths" (Richardson and others, 1993, p. 48). Many factors, including historical performance during flood events, the geomorphic assessment, scour protection measures, and the results of the hydraulic analyses, must be considered to properly assess the validity of abutment scour results. Therefore, scour depths adopted by VTAOT may differ from the computed values documented herein, based on the consideration of additional contributing factors and experienced engineering judgement. 


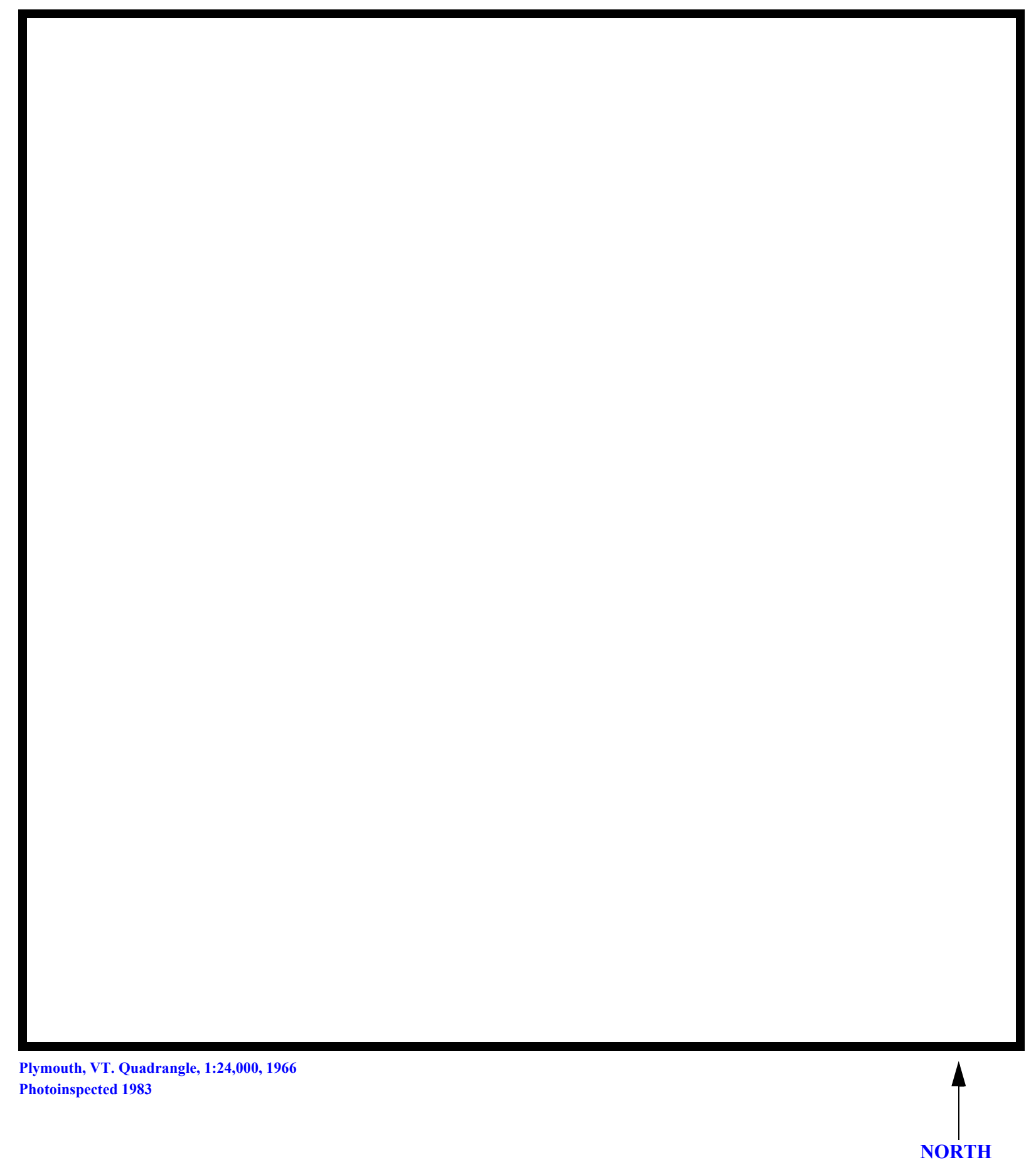

Figure 1. Location of study area on USGS 1:24,000 scale map. 
Figure 2. Location of study area on Vermont Agency of Transportation town highway map. 

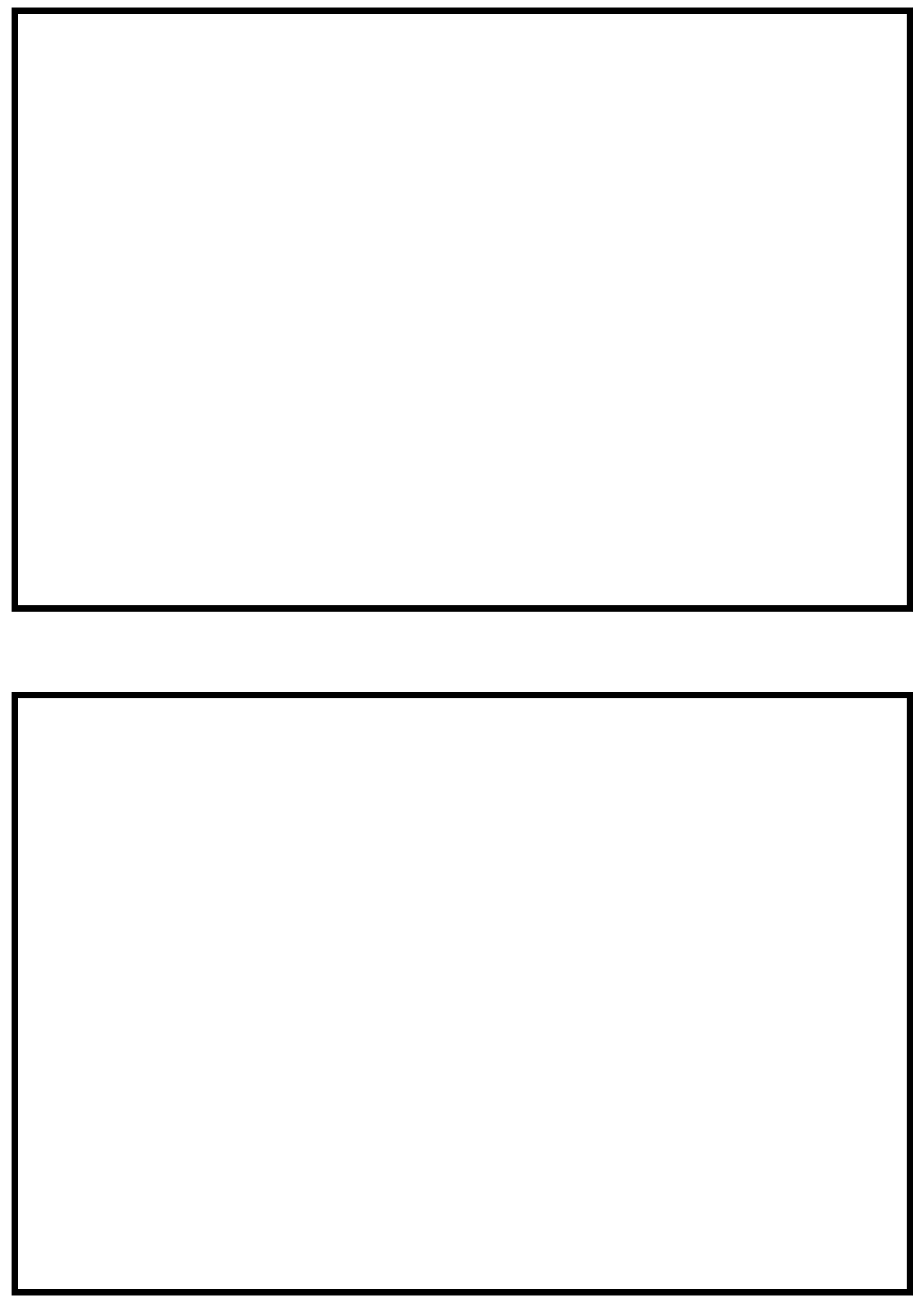

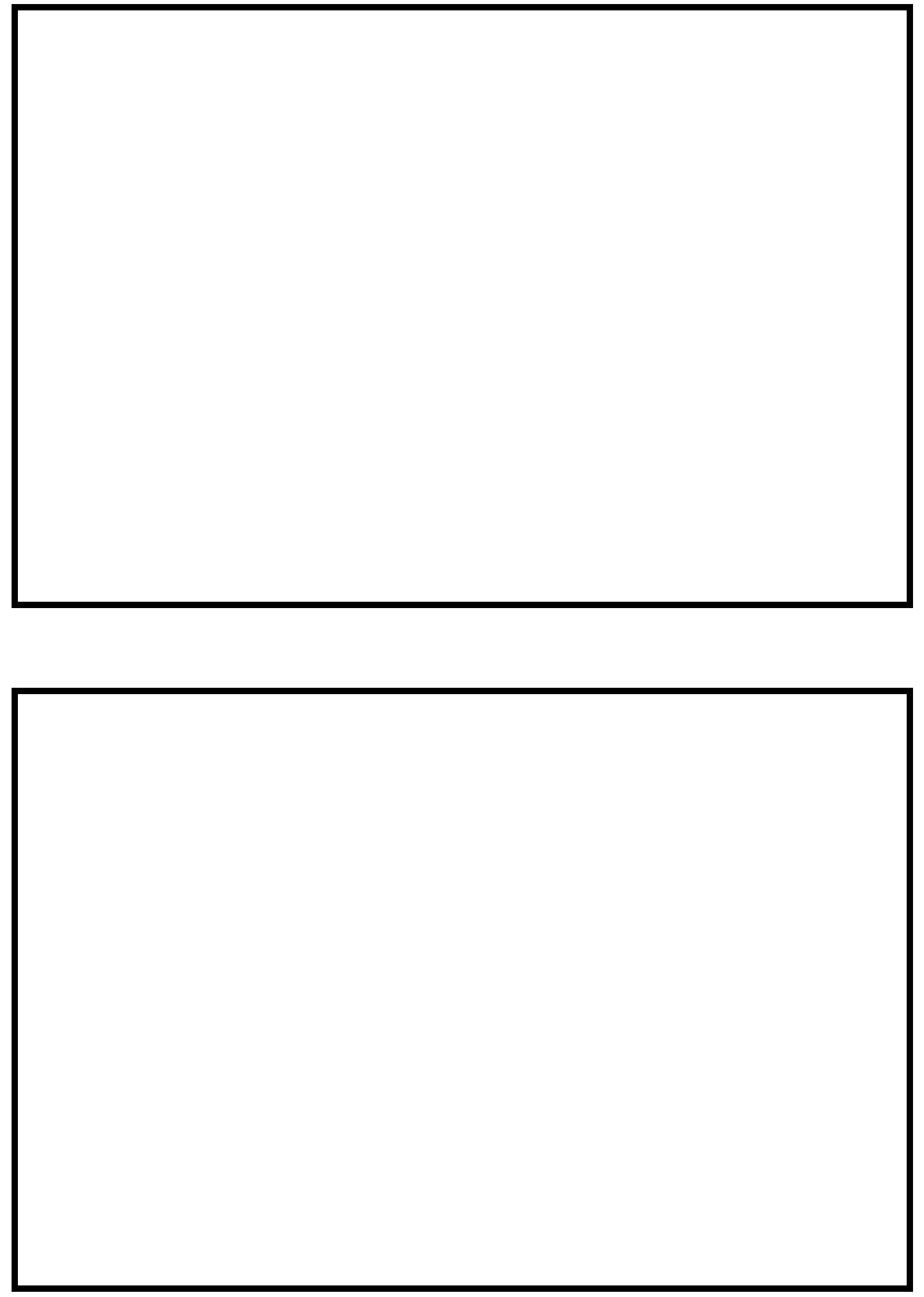


\section{LEVEL II SUMMARY}

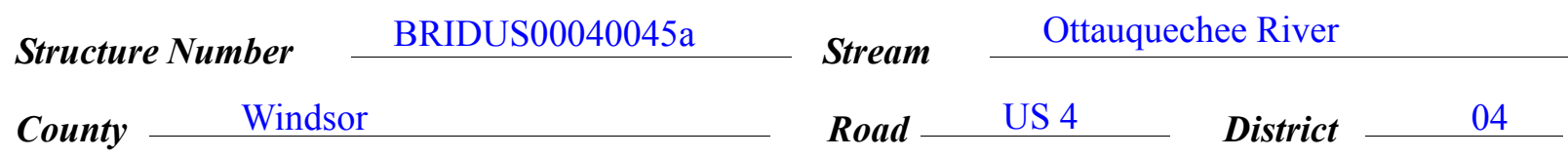

\section{Description of Bridge}

Bridge length $\frac{172}{f t}$ Bridge width $\frac{35.2}{f t}$ Max span length $\frac{72}{f t}$ Alignment of bridge to road (on curve or straight) spill-through

Abutment type

Stone fill on abutment?

yes

Embankment type slight horizontal curve

sloping

$10 / 26 / 94$

Drto of incnortion

Type-2 protecting each abutment and the road embankment.

Marmintinu af atom a fill

Abutments and piers are concrete. The piers are located

at the toe of each of the spill-through abutments.

\section{$\mathrm{Y}$}

Is bridge skewed to flood flow according to Y Y survey?

Angle

Bridge is located on a mild bend in the channel.

Debris accumulation on bridge at time of Level I or Level II site visit:

Date of incnortion $10 / 26 / 94$

Level I

$10 / 26 / 94$

Level II piers.

Potential for debris

\section{Percent of ahminal blocked inortzontatly}

Low; however, capture efficiency may be significant due to the two

October 26, 1994. There is a significant tributary 200 feet upstream of the bridge.

Dosriho anv, fonturos noar ar at tho hridoo that mav affort flow, (includo ahsorvation dato) 


\section{Description of the Geomorphic Setting}

General topography At the study site, the channel is sinuous with narrow flood plains in a moderate relief valley.

Geomorphic conditions at bridge site: downstream (DS), upstream (US)

Date of inspection $\quad 10 / 26 / 94$

DS left: $\quad$ Flood plain to steep valley wall.

DS right: $\quad$ Narrow flood plain to steep valley wall.

US left: $\quad$ Flood plain to steep valley wall.

US right: $\quad$ Flood plain to steep valley wall.

\section{Description of the Channel}

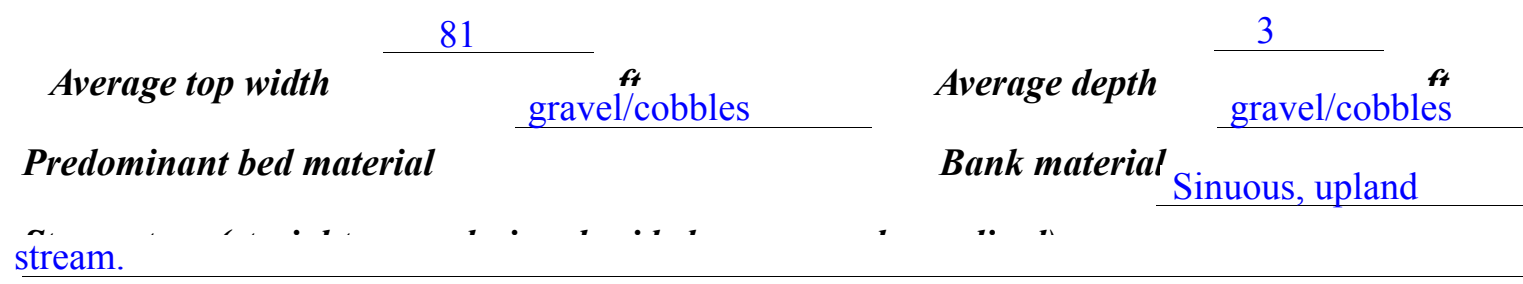

Vegetative co ${ }^{1}$ Immediate bank is forested overbank is pasture.

DS left: $\quad$ Immediate bank is lawn within one bridge length; forest cover beyond.

DS right: $\quad$ Immediate bank is forested with lawn on the overbank.

US left: $\quad$ Immediate bank is covered by brush with lawn on the overbank.

US right: $\quad \underline{\mathrm{Y}}$

Do banks appear stable? 10/26/94.

date of observatton.

$10 / 26 / 94$

dete of obser

10/26/94--None.

Describe any obstructions in channel and date of observation. 


\section{Hydrology}

Drainage area $\frac{72.1}{\boldsymbol{m i}^{2}}$

Percentage of drainage area in physiographic provinces: (approximate)

Physiographic province

Green Mountain
Percent of drainage area

100

Is drainage area considered rural or urban? Rural Describe any significant

urbanization: $\quad$ None. Area is mostly forested, high-elevation, headwater drainage.

Is there a USGS gage on the stream of interest?

No

\section{USGS gage description}

USGS gage number

Gage drainage area

$m i^{2}$

No

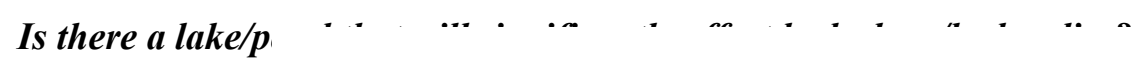

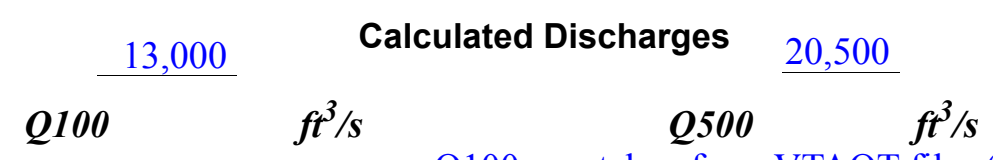

Q100 was taken from VTAOT files (written

commun., 5/4/95). Q500 was determined by graphically extrapolating flood frequency estimates in the VTAOT files. The results were also compared with various empirical methods (Talbot,

1887; Potter, 1957a; Potter, 1957b; Johnson and Laraway, 1971, written commun.; Johnson and Tasker, 1974; Federal Highway Administration, 1983). 


\section{Description of the Water-Surface Profile Model (WSPRO) Analysis}

Datum for WSPRO analysis (USGS survey, sea level, VTAOT plans)

USGS survey

Datum tie between USGS survey and VTAOT plans

Add $767 \mathrm{ft}$ to USGS datum to get

VTAOT plans datum.

Description of reference marks used to determine USGS datum. $\quad$ RM1 is a bronze tablet near the downstream end of the right abutment (elev. 103.48 feet, arbitrary survey datum). RM2

is a chiseled $\mathrm{X}$ on the upstream left corner of the bridge (elev. 100.84 feet, arbitrary survey

datum).

\section{Cross-Sections Used in WSPRO Analysis}

\begin{tabular}{cccl}
\hline${ }^{1}$ Cross-section & $\begin{array}{c}\text { Section } \\
\text { Reference } \\
\text { Distance } \\
\text { (SRD) in feet }\end{array}$ & $\begin{array}{c}{ }^{2} \text { Cross-section } \\
\text { development }\end{array}$ & \multicolumn{1}{c}{ Comments } \\
\hline EXITX & 0 & 1 & Exit section \\
FULLV & 74 & 2 & $\begin{array}{l}\text { Downstream Full-valley } \\
\text { section (Templated from } \\
\text { EXITX) }\end{array}$ \\
BRIDG & 74 & 1 & Bridge section \\
RDWAY & 92 & 1 & Road Grade section \\
APPRO & 174 & 1 & Approach section \\
\hline
\end{tabular}

${ }^{1}$ For location of cross-sections see plan-view sketch included with Level I field form, Appendix E. For more detail on how cross-sections were developed see WSPRO input file. 


\section{Data and Assumptions Used in WSPRO Model}

Hydraulic analyses of the reach were done by use of the Federal Highway Administration's WSPRO step-backwater computer program (Shearman and others, 1986, and Shearman, 1990). Results of the hydraulic model are presented in the Bridge Hydraulic Summary, Appendix B, and figure 7.

Channel roughness factors (Manning's " $\mathrm{n}$ ") used in the hydraulic model were estimated using field inspections at each cross section following the general guidelines described by Arcement, Jr. and Schneider (1989). Final adjustments to the values were made during the modelling of the reach. Channel " $n$ " values for the reach were 0.045 , and overbank "n" values ranged from 0.075 to 0.085 .

Normal depth at the exit section (EXITX) was assumed as the starting water surface. This depth was computed by use of the slope-conveyance method outlined in the User's manual for WSPRO (Shearman, 1990). The slope used was $0.010 \mathrm{ft} / \mathrm{ft}$ which was estimated from thalweg points surveyed downstream of the bridge.

For the 100-year discharge of 13,000 cfs and the incipient overtopping discharge of $19,540 \mathrm{cfs}$, WSPRO assumes critical depth at the bridge section. Further analysis, in which the water surface is shown to pass through critical depth in the bridge, suggests the critical depth assumtions at the bridge section are satisfactory solutions. 


\section{Bridge Hydraulics Summary}

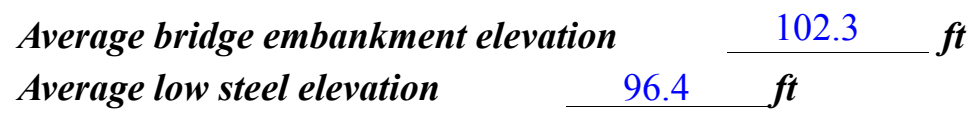

100-year discharge $13,000 \quad \mathrm{ft}^{3} / \mathrm{s}$

Water-surface elevation in bridge opening $\quad \begin{array}{lll}90.8 \quad \boldsymbol{t} \\ \end{array}$

Road overtopping? ___ N Discharge over road __ _ _ _. s

Area of flow in bridge opening $\quad 923 \quad \boldsymbol{f t}^{2}$

Average velocity in bridge opening $14.1 \mathrm{ft} / \mathrm{s}$

$\begin{array}{llll}\text { Maximum WSPRO tube velocity at bridge } & 16.7 & \mathrm{ft} / \mathrm{s}\end{array}$

Water-surface elevation at Approach section with bridge 93.8

Water-surface elevation at Approach section without bridge $\quad 91.8$

Amount of backwater caused by bridge $\quad 2.0 \quad$ it

500-year discharge $\quad 20,500 \quad \mathrm{ft}^{3} / \mathrm{s}$

Water-surface elevation in bridge opening $\quad 96.8 \quad f t$

Road overtopping? ___ Y Discharge over road _ $107, \% / s$

Area of flow in bridge opening $\quad 1590 \quad \mathrm{ft}^{2}$

Average velocity in bridge opening $\quad 12.8 \quad \mathbf{f t} / \mathbf{s}$

Maximum WSPRO tube velocity at bridge $\quad 14.0_{\text {_'s }}$

Water-surface elevation at Approach section with bridge

Water-surface elevation at Approach section without bridge

101.6

Amount of backwater caused by bridge 7.9 .

Incipient overtopping discharge $\quad 19,540 \quad \mathrm{ft}^{3} / \mathrm{s}$

Water-surface elevation in bridge opening $\quad 93.2 \quad t_{t}$

Area of flow in bridge opening $\quad 1240 \quad \boldsymbol{f t}^{2}$

Average velocity in bridge opening $\quad 15.7 \quad \mathrm{ft} / \mathrm{s}$

Maximum WSPRO tube velocity at bridge $\quad 18.9 \quad \mathrm{ft} / \mathrm{s}$

Water-surface elevation at Approach section with bridge

Water-surface elevation at Approach section without bridge

96.9

Amount of backwater caused by bridge $\quad 3.4$ it 


\section{Scour Analysis Summary}

\section{Special Conditions or Assumptions Made in Scour Analysis}

Scour depths were computed using the general guidelines described in Hydraulic Engineering Circular 18 (Richardson and others, 1993). Scour depths were calculated assuming an infinite depth of erosive material and a homogeneous particle-size distribution. The results of the scour analysis are presented in tables 1 and 2 and a graph of the scour depths is presented in figure 8 .

Contraction scour for the 100-year and the incipient overtopping discharges were computed by use of the live-bed contraction scour equation (Richardson and others, 1993, p. 33, equation 16,17). The 500-year discharge resulted in orifice flow and contraction scour was computed by use of the Chang equation (Richardson and others, 1995, p. 145-146). Contraction scour at bridges with orifice flow is best estimated by use of the Chang pressureflow scour equation (oral communication, J. Sterling Jones, October 4, 1996). The results of Laursen's clear-water contraction scour (Richardson and others, 1993, p. 35, equation 18,19) for the 500-year event were also computed and can be found in appendix F. For contraction scour computations using the Laursen's equation, the average depth in the contracted section (AREA/TOPWIDTH) is subtracted from the depth of flow computed by the scour equation (Y2) to determine the actual amount of scour.

Abutment scour was computed by the Froehlich equation (Richardson and others, 1993, p. 49, equation 24). Variables for the Froehlich equation include the Froude number of the flow approaching the embankments, the length of the embankment blocking flow, and the depth of flow approaching the embankment less any roadway overtopping.

Pier scour was computed by use of the Colorado State University pier scour equation (Richardson and others, 1993, p.39, equation 21).

The results of the scour computations are plotted in figure 7. Since the toes of the spill-through abutments are at the piers, the abutment scour depth was subtracted from the channel elevation of the bankward side of the respective pier. The pier scour was subtracted from the channel elevation at the pier nose. Only the worst case of the abutment and pier scour results was plotted. Abutment scour and pier scour are not considered additive. 


\section{Scour Results}

100-yr discharge 500-yr discharge

overtopping

Contraction scour:

(Scour depths in feet)

Main channel

Live-bed scour

Clear-water scour

Depth to armoring

Left overbank

Right overbank

Local scour:

Abutment scour

15.0

14.4

9.3

Left abutment

15.2

11.9-

$11.4-$

\section{Right abutment}

Pier scour

Pier 1

11.5

12.4

11.4

11.5

12.4

Pier 2

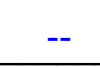

$--$

$\frac{4.0}{\mathrm{~N} / \mathrm{A}}$

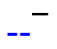

$--$

Pier 3

\section{Rock Riprap Sizing}

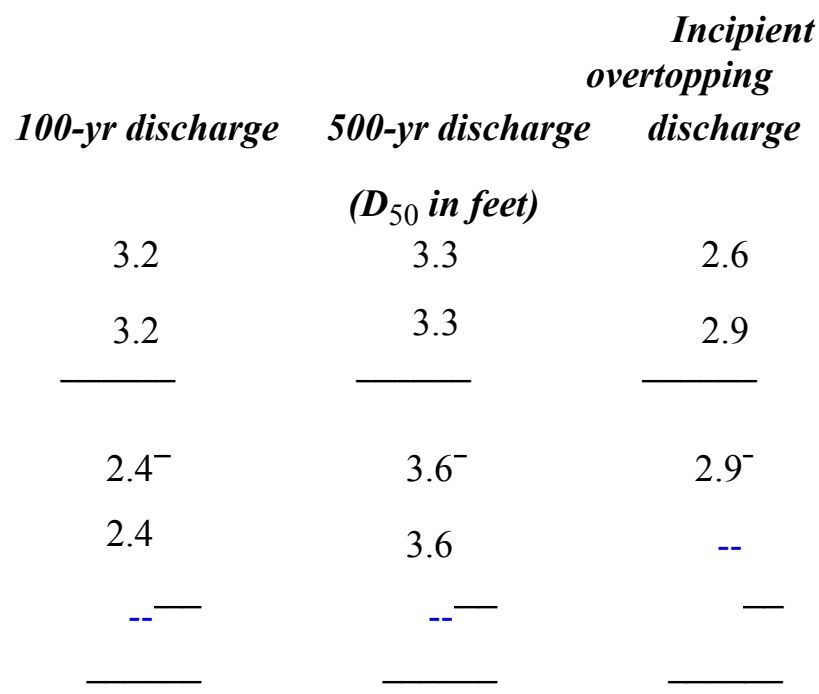




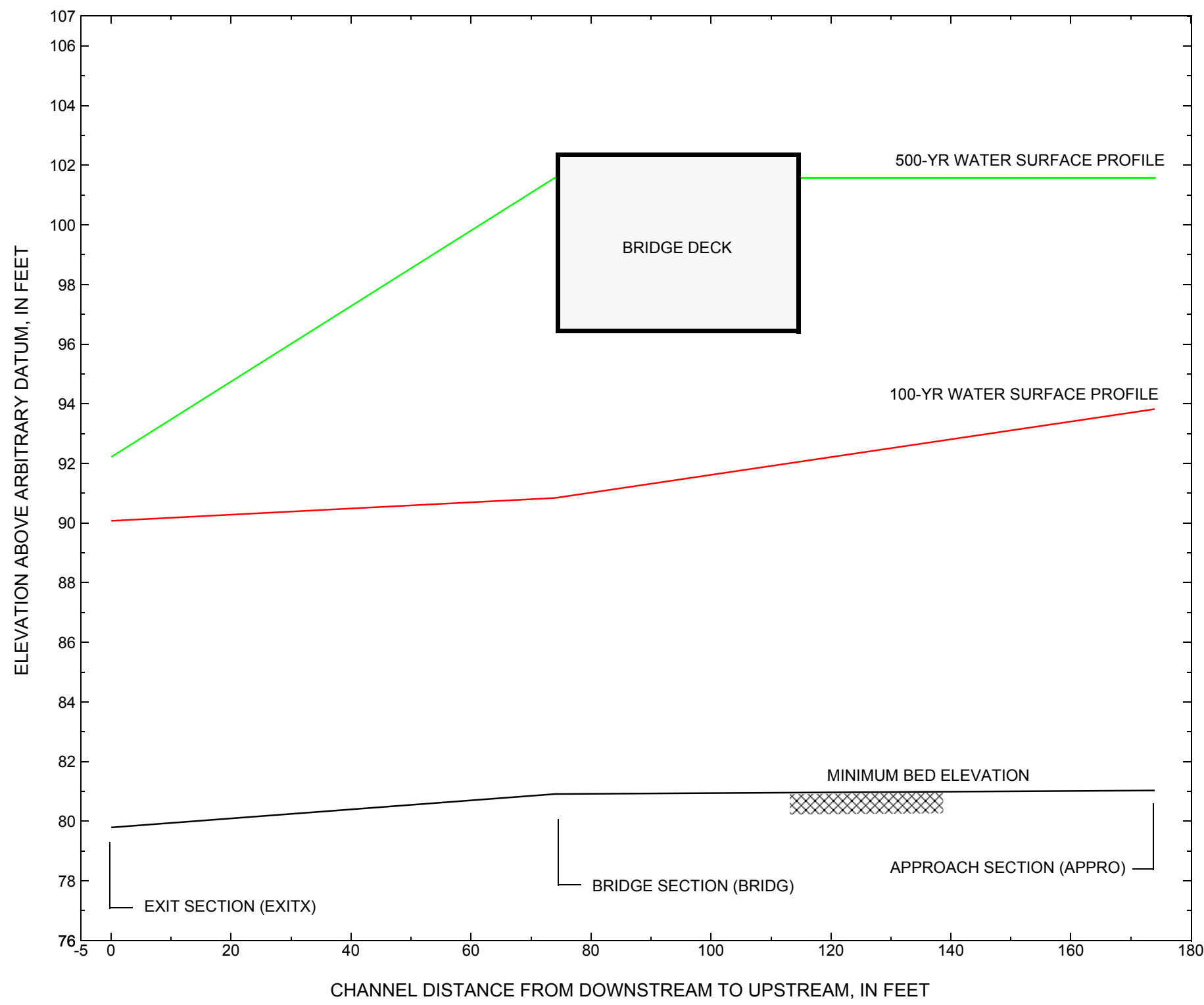

Figure 7. Water-surface profiles for the 100- and 500-yr discharges at structure BRIDUS00040045a on U.S. Route 4, crossing the Ottauquechee River, Bridgewater, Vermont. 


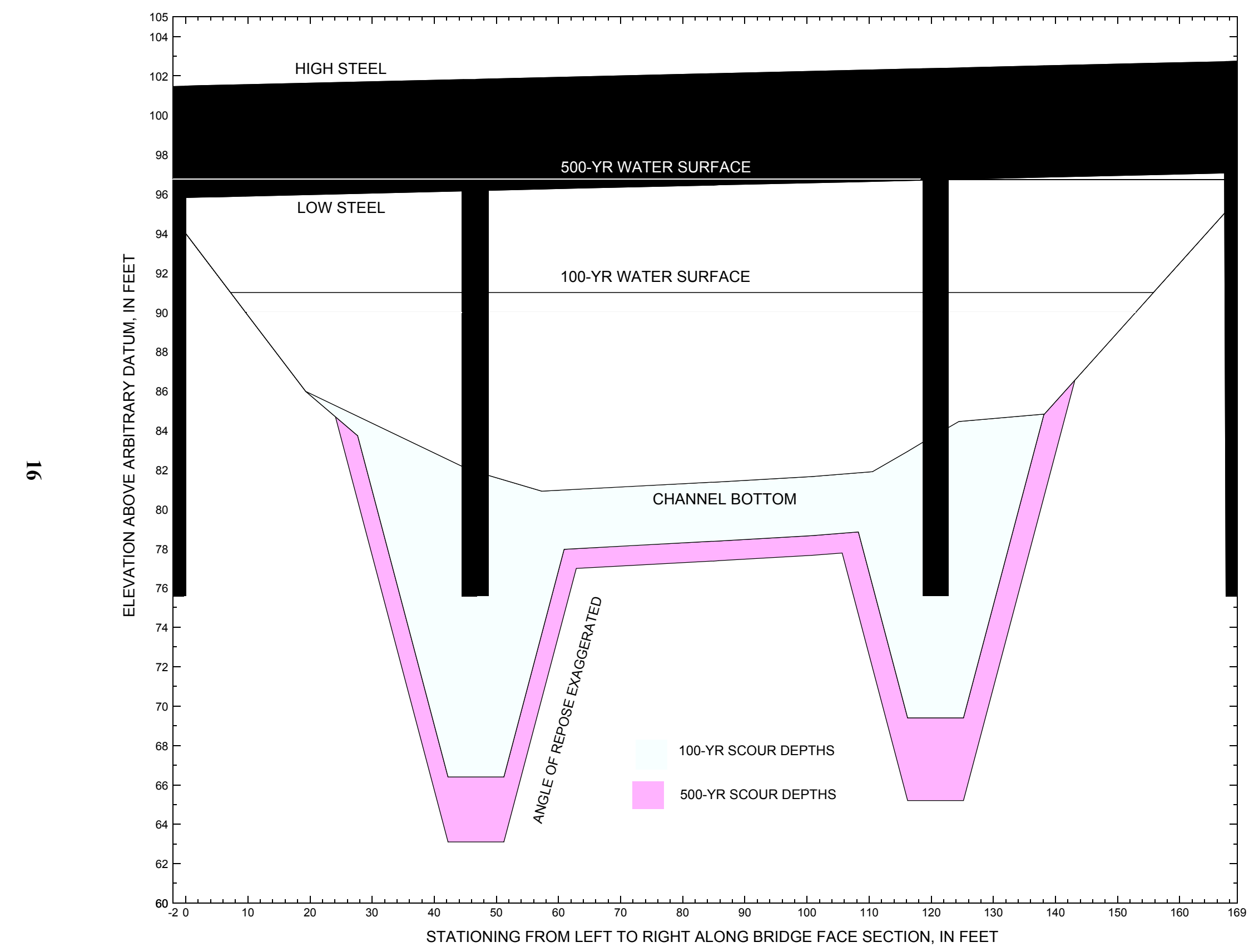

Figure 8. Scour elevations for the 100-yr and 500-yr discharges at structure BRIDUS00040045a on U.S. Route 4, crossing the Ottauquechee River, Bridgewater, Vermont. 
Table 1. Remaining footing/pile depth at abutments for the 100-year discharge at structure BRIDUS00040045a on U.S. Route 4, crossing the Ottauquechee River, Bridgewater, Vermont.

[VTAOT, Vermont Agency of Transportation; --,no data]

\begin{tabular}{|c|c|c|c|c|c|c|c|c|c|c|c|}
\hline Description & Station $^{1}$ & $\begin{array}{l}\text { VTAOT } \\
\text { plans' } \\
\text { bridge seat } \\
\text { elevation } \\
\text { (feet) }\end{array}$ & $\begin{array}{l}\text { Surveyed } \\
\text { minimum } \\
\text { low-chord } \\
\text { elevation } \\
\text { (feet) }\end{array}$ & $\begin{array}{c}\text { Bottom of } \\
\text { footing } \\
\text { elevation } \\
\text { (feet) }\end{array}$ & $\begin{array}{c}\text { Channel } \\
\text { elevation at } \\
\text { abutment/ } \\
\text { pier }^{2} \\
\text { (feet) }\end{array}$ & $\begin{array}{l}\text { Contraction } \\
\text { scour depth } \\
\text { (feet) }\end{array}$ & $\begin{array}{l}\text { Abutment } \\
\text { scour } \\
\text { depth } \\
\text { (feet) }\end{array}$ & $\begin{array}{l}\text { Pier } \\
\text { scour } \\
\text { depth } \\
\text { (feet) }\end{array}$ & $\begin{array}{l}\text { Depth of } \\
\text { total scour } \\
\text { (feet) }\end{array}$ & $\begin{array}{c}\text { Elevation of } \\
\text { scour }^{2} \\
\text { (feet) }\end{array}$ & $\begin{array}{c}\text { Remaining } \\
\text { footing/pile } \\
\text { depth } \\
\text { (feet) }\end{array}$ \\
\hline \multicolumn{12}{|c|}{100 -yr. discharge is 13,000 cubic-feet per second } \\
\hline Left abutment & 0.0 & 863.2 & 95.8 & 76 & -- & -- & -- & -- & -- & -- & -- \\
\hline Left abutment toe & 44.7 & -- & -- & 76 & 82.1 & 3.1 & 12.7 & -- & 15.8 & 66.3 & -10 \\
\hline Left pier & 46.7 & -- & -- & 76 & 81.9 & 3.1 & -- & 11.4 & 14.5 & 67.4 & -9 \\
\hline Right pier & 120.7 & -- & -- & 76 & 83.8 & 3.1 & -- & 11.4 & 14.5 & 69.3 & -7 \\
\hline Right abutment toe & 124.4 & -- & -- & 76 & 84.4 & 3.1 & 9.3 & -- & 12.4 & 72.0 & -4 \\
\hline Right abutment & 167.2 & 864.5 & 97.0 & 76 & -- & -- & -- & -- & -- & -- & -- \\
\hline
\end{tabular}

${ }^{1 .}$ Measured along the face of the most constricting side of the bridge

2. Arbitrary datum for this study.

Table 2. Remaining footing/pile depth at abutments for the 500-year discharge at structure BRIDUS00040045a on U.S. Route 4, crossing the Ottauquechee River, Bridgewater, Vermont.

[VTAOT, Vermont Agency of Transportation; --, no data]

\begin{tabular}{|c|c|c|c|c|c|c|c|c|c|c|c|}
\hline Description & Station $^{1}$ & $\begin{array}{c}\text { VTAOT } \\
\text { plans' } \\
\text { bridge seat } \\
\text { elevation } \\
\text { (feet) }\end{array}$ & $\begin{array}{c}\text { Surveyed } \\
\text { minimum } \\
\text { low-chord } \\
\text { elevation } \\
\text { (feet) }\end{array}$ & $\begin{array}{c}\text { Bottom of } \\
\text { footing } \\
\text { elevation } \\
\text { (feet) }\end{array}$ & $\begin{array}{c}\text { Channel } \\
\text { elevation at } \\
\text { abutment/ } \\
\text { pier }^{2} \\
\text { (feet) }\end{array}$ & $\begin{array}{c}\text { Contraction } \\
\text { scour depth } \\
\text { (feet) }\end{array}$ & $\begin{array}{l}\text { Abutment } \\
\text { scour } \\
\text { depth } \\
\text { (feet) }\end{array}$ & $\begin{array}{l}\text { Pier } \\
\text { scour } \\
\text { depth } \\
\text { (feet) }\end{array}$ & $\begin{array}{l}\text { Depth of } \\
\text { total scour } \\
\text { (feet) }\end{array}$ & $\begin{array}{c}\text { Elevation of } \\
\text { scour }^{2} \\
\text { (feet) }\end{array}$ & $\begin{array}{c}\text { Remaining } \\
\text { footing/pile } \\
\text { depth } \\
\text { (feet) }\end{array}$ \\
\hline \multicolumn{12}{|c|}{500 -yr. discharge is 20,500 cubic-feet per second } \\
\hline Left abutment & 0.0 & 863.2 & 95.8 & 76 & -- & -- & -- & -- & -- & -- & -- \\
\hline Left abutment toe & 44.7 & -- & -- & 76 & 82.1 & 4.0 & 15.0 & -- & 19.0 & 63.1 & -13 \\
\hline Left pier & 46.7 & -- & -- & 76 & 81.9 & 4.0 & -- & 11.5 & 15.5 & 66.4 & -10 \\
\hline Right pier & 120.7 & -- & -- & 76 & 83.8 & 4.0 & -- & 11.5 & 15.5 & 68.3 & -8 \\
\hline Right abutment toe & 124.4 & -- & -- & 76 & 84.4 & 4.0 & 15.2 & -- & 19.2 & 65.2 & -11 \\
\hline Right abutment & 167.2 & 864.5 & 97.0 & 76 & -- & -- & -- & -- & -- & -- & -- \\
\hline
\end{tabular}

1. Measured along the face of the most constricting side of the bridge

2. Arbitrary datum for this study. 


\section{SELECTED REFERENCES}

Arcement, G.J., Jr., and Schneider, V.R., 1989, Guide for selecting Manning's roughness coefficients for natural channels and flood plains: U.S. Geological Survey Water-Supply Paper 2339, 38 p.

Barnes, H.H., Jr., 1967, Roughness characteristics of natural channels: U.S. Geological Survey Water-Supply Paper 1849, 213 p.

Brown, S.A. and Clyde, E.S., 1989, Design of riprap revetment: Federal Highway Administration Hydraulic Engineering Circular No. 11, Publication FHWA-IP-89-016, 156 p.

Federal Highway Administration, 1983, Runoff estimates for small watersheds and development of sound design: Federal Highway Administration Report FHWA-RD-77-158

Federal Emergency Management Agency, 1980, Flood Insurance Study, Town of Bridgewater, Windsor County, Vermont: Washington, D.C., January 1980.

Froehlich, D.C., 1989, Local scour at bridge abutments in Ports, M.A., ed., Hydraulic Engineering--Proceedings of the 1989 National Conference on Hydraulic Engineering: New York, American Society of Civil Engineers, p. 13-18.

Hayes, D.C.,1993, Site selection and collection of bridge-scour data in Delaware, Maryland, and Virginia: U.S. Geological Survey Water-Resources Investigation Report 93-4017, 23 p.

Interagency Advisory Committee on Water Data, 1982, Guidelines for determining flood flow frequency: U.S. Geological Survey, Bulletin 17B of the Hydrology Subcommittee, 190 p.

Johnson, C.G. and Tasker, G.D.,1974, Progress report on flood magnitude and frequency of Vermont streams: U.S. Geological Survey Open-File Report 74-130, 37 p.

Laursen, E.M., 1960, Scour at bridge crossings: Journal of the Hydraulics Division, American Society of Civil Engineers, v. 86, no. HY2, p. 39-53.

Potter, W. D., 1957a, Peak rates of runoff in the Adirondack, White Mountains, and Maine woods area, Bureau of Public Roads

Potter, W. D., 1957b, Peak rates of runoff in the New England Hill and Lowland area, Bureau of Public Roads

Richardson, E.V. and Davis, S.R., 1995, Evaluating scour at bridges: Federal Highway Administration Hydraulic Engineering Circular No. 18, Publication FHWA-IP-90-017, 204 p.

Richardson, E.V., Harrison, L.J., Richardson, J.R., and Davis, S.R., 1993, Evaluating scour at bridges: Federal Highway Administration Hydraulic Engineering Circular No. 18, Publication FHWA-IP-90-017, 131 p.

Richardson, E.V., Simons, D.B., and Julien, P.Y., 1990, Highways in the river environment: Federal Highway Administration Publication FHWA-HI-90-016.

Ritter, D.F., 1984, Process Geomorphology: W.C. Brown Co., Debuque, Iowa, 603 p.

Shearman, J.O., 1990, User's manual for WSPRO--a computer model for water surface profile computations: Federal Highway Administration Publication FHWA-IP-89-027, 187 p.

Shearman, J.O., Kirby, W.H., Schneider, V.R., and Flippo, H.N., 1986, Bridge waterways analysis model; research report: Federal Highway Administration Publication FHWA-RD-86-108, 112 p.

Talbot, A.N., 1887, The determination of water-way for bridges and culverts.

U.S. Department of Transportation, 1993, Stream stability and scour at highway bridges, Participant Workbook: Federal Highway Administration Publication FHWA HI-91-011.

U.S. Geological Survey, 1966, Plymouth, Vermont 7.5 Minute Series quadrangle map: U.S. Geological Survey Topographic Maps, Photoinspected 1983, Scale 1:24,000. 


\section{APPENDIX A: \\ WSPRO INPUT FILE}




\section{WSPRO INPUT FILE}

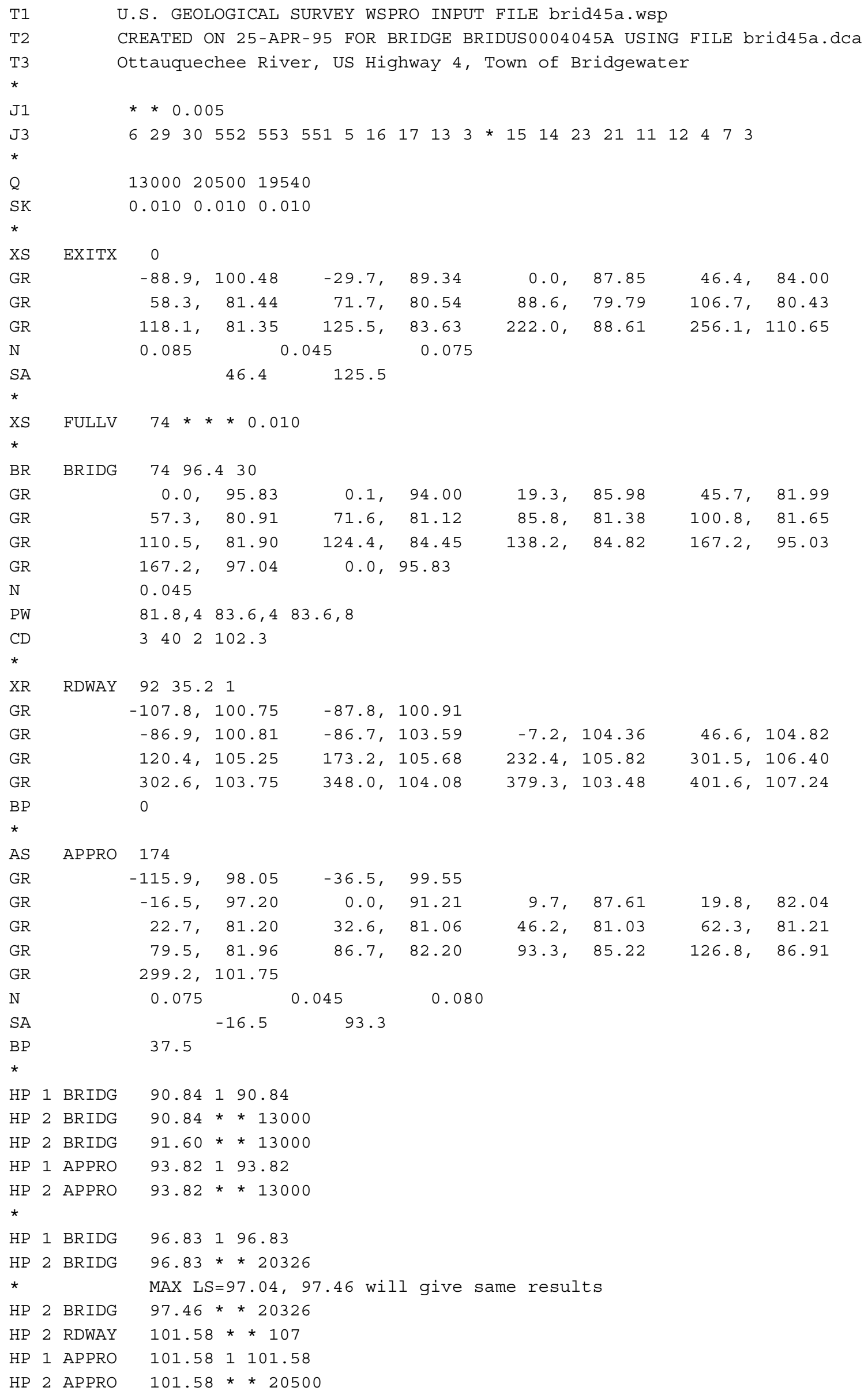




\section{APPENDIX B: \\ WSPRO OUTPUT FILE}




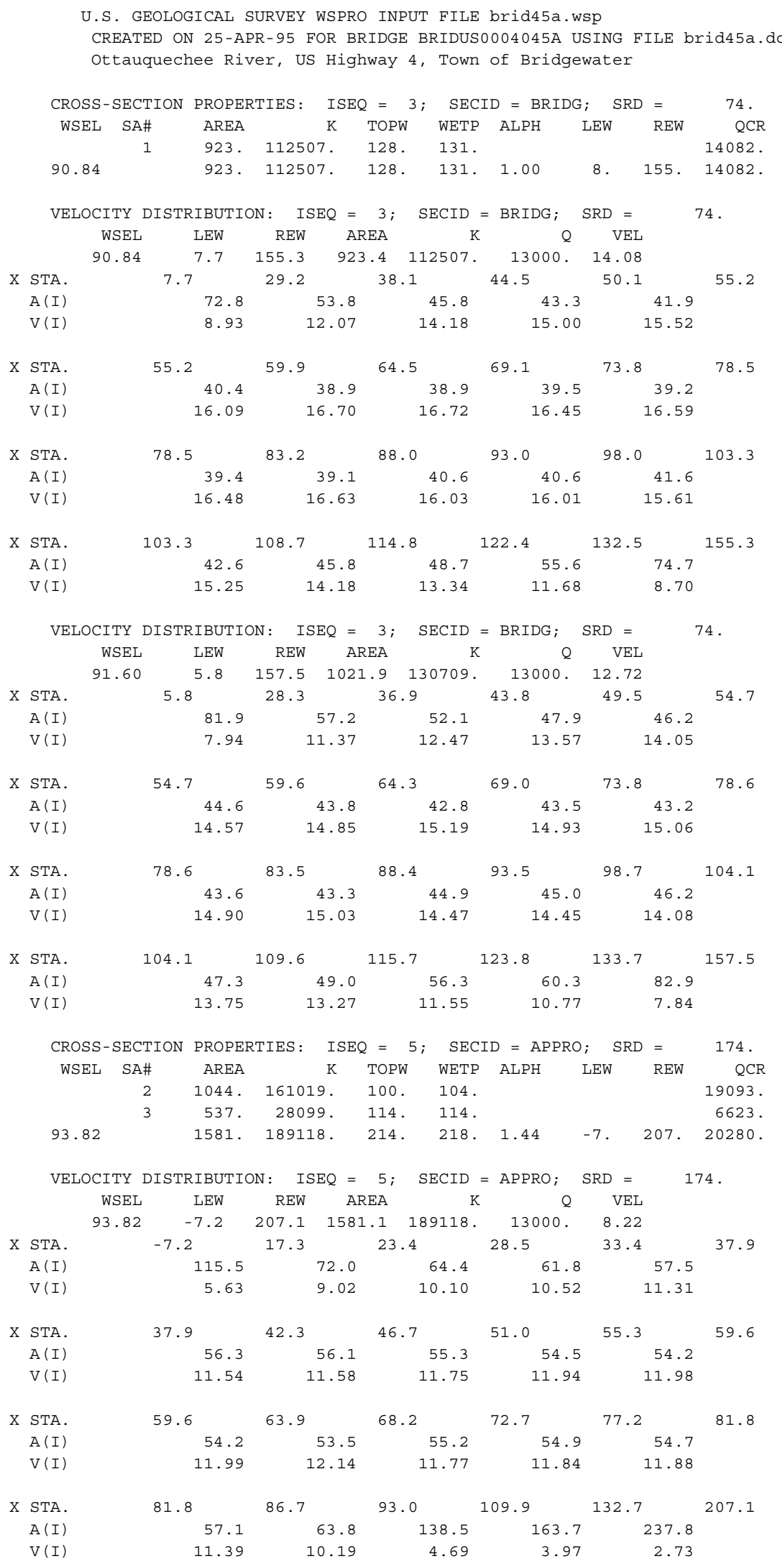


WSPRO OUTPUT FILE (continued)

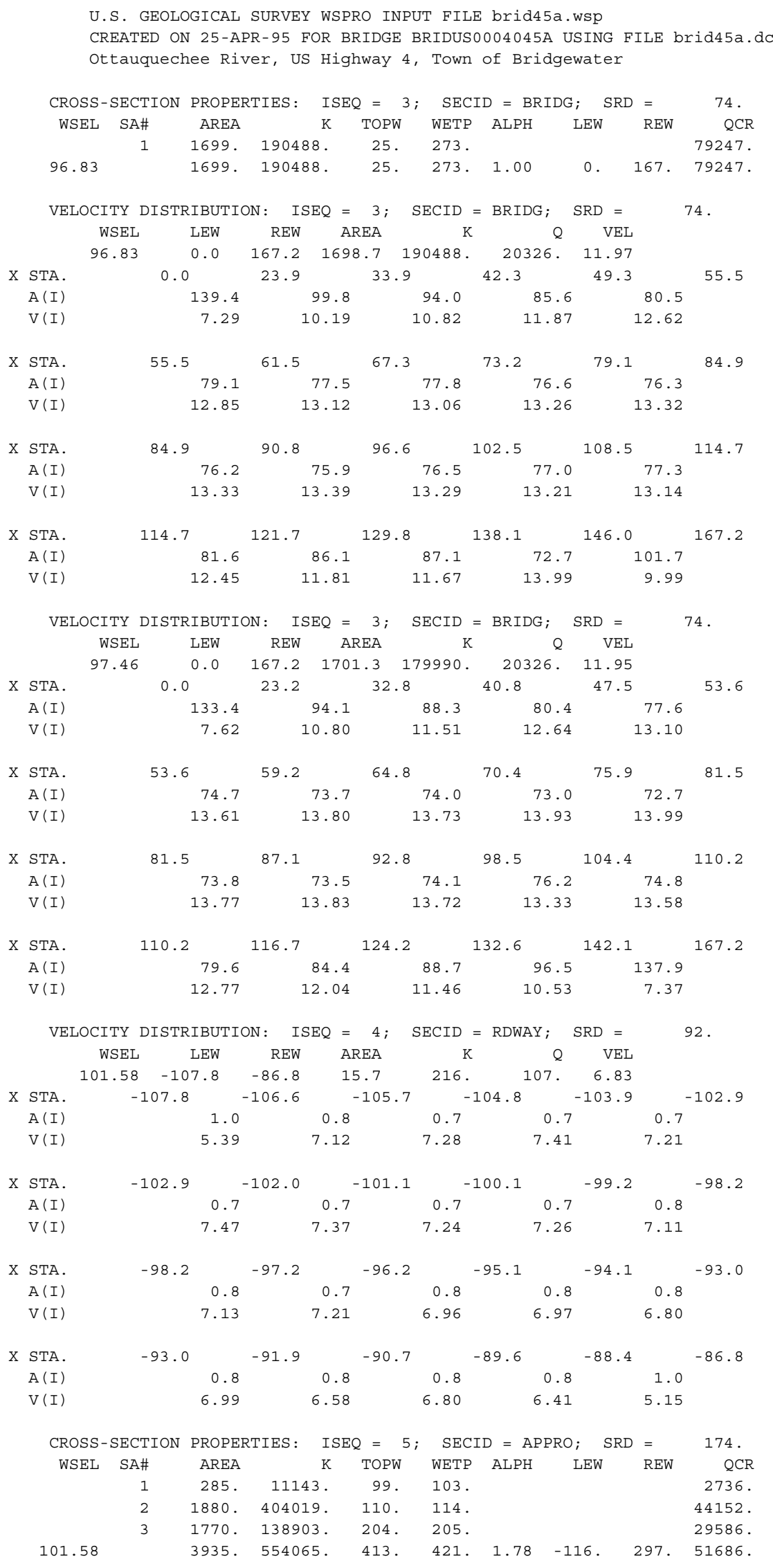


WSPRO OUTPUT FILE (continued)

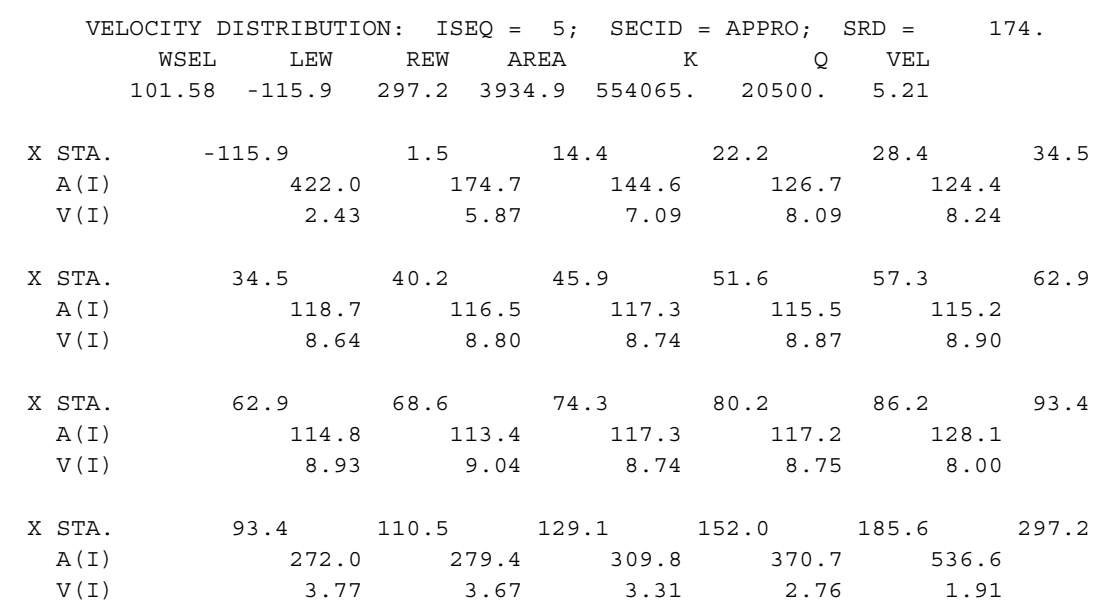

U.S. GEOLOGICAL SURVEY WSPRO INPUT FILE brid45a.wsp

CREATED ON 25-APR-95 FOR BRIDGE BRIDUS0004045A USING FILE brid45a.dca Ottauquechee River, US Highway 4, Town of Bridgewater

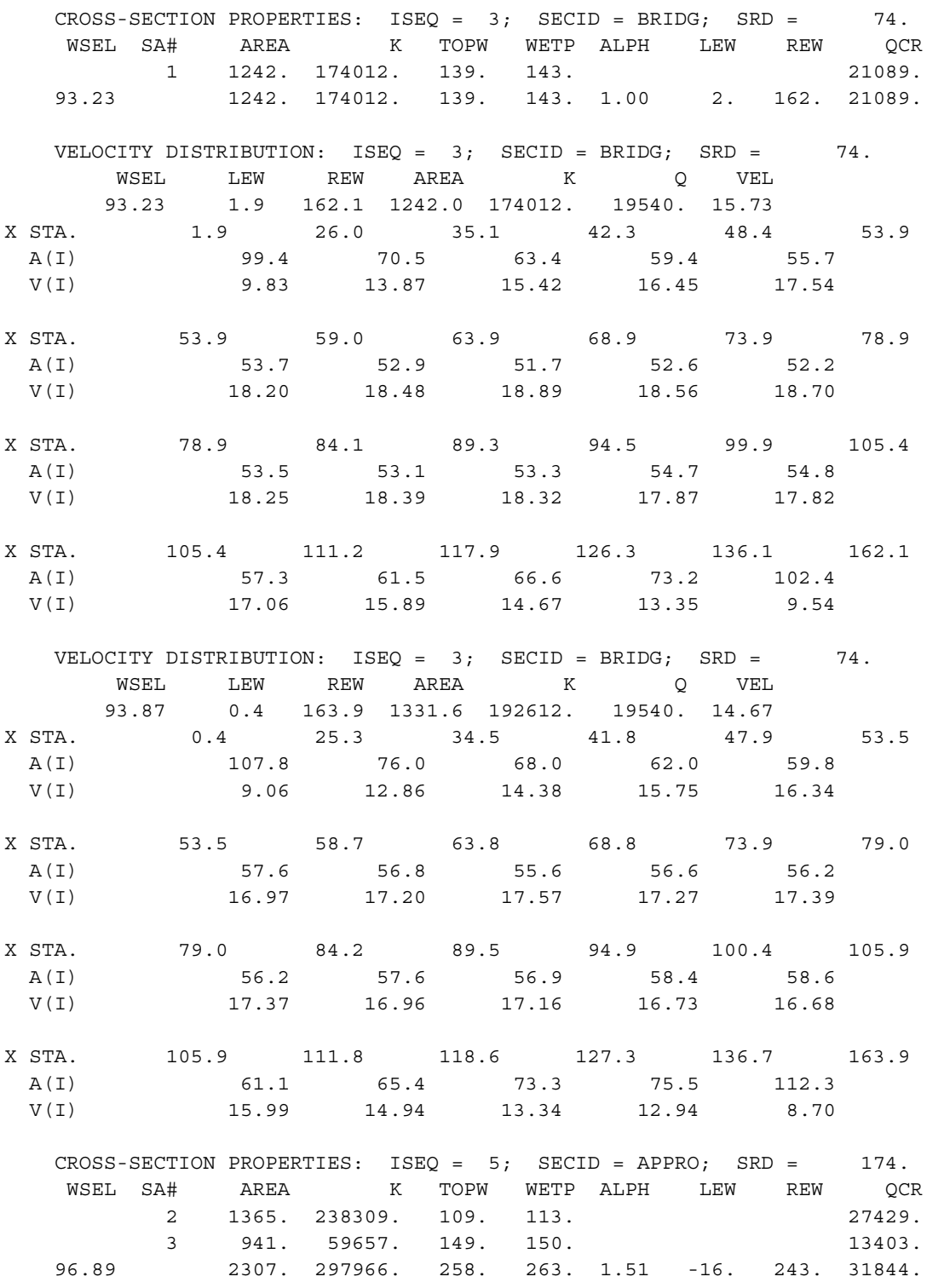


WSPRO OUTPUT FILE (continued)

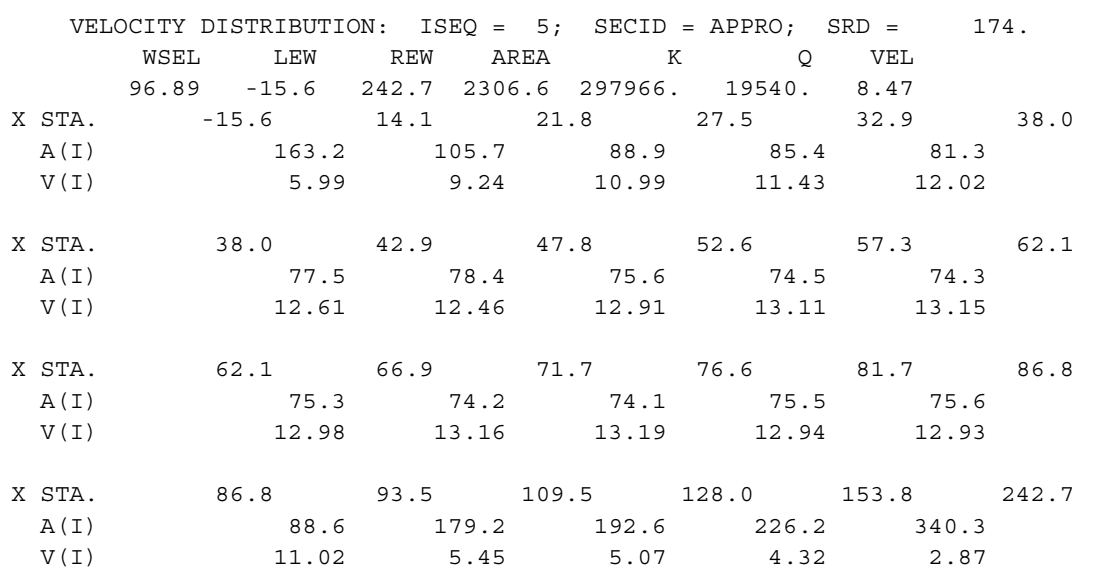

U.S. GEOLOGICAL SURVEY WSPRO INPUT FILE brid45a.wSP

CREATED ON 25-APR-95 FOR BRIDGE BRIDUS0004045A USING FILE brid45a.dca Ottauquechee River, US Highway 4, Town of Bridgewater *** RUN DATE \& TIME: 12-01-95 13:30

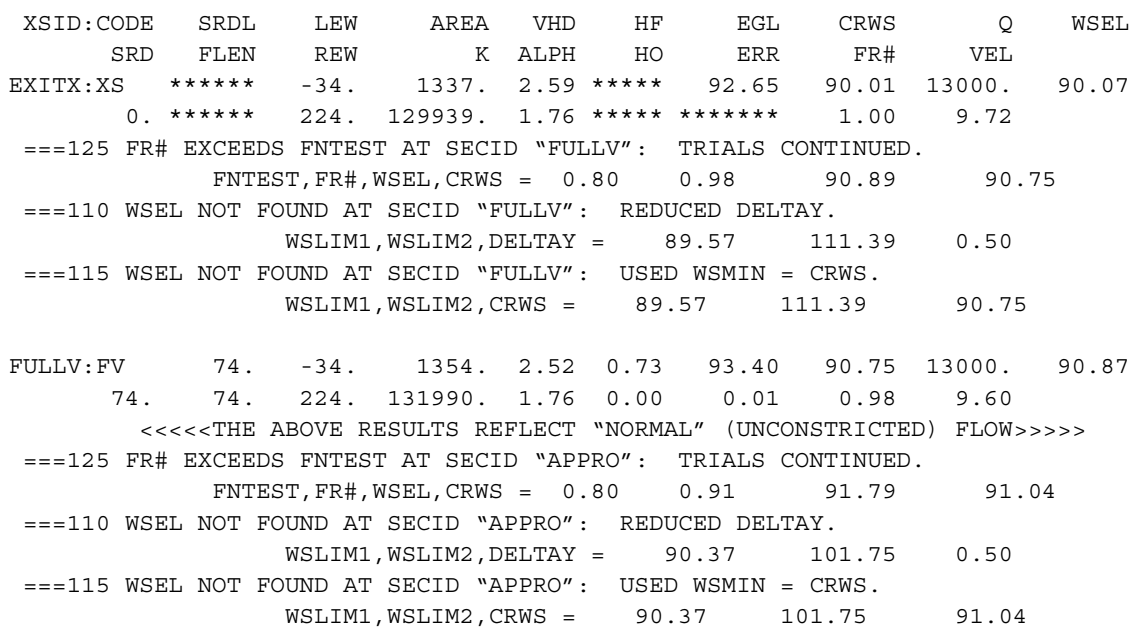

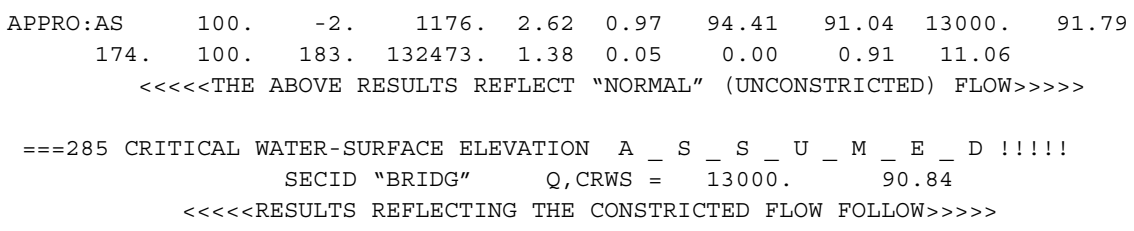


WSPRO OUTPUT FILE (continued)

\begin{tabular}{|c|c|c|c|c|c|c|c|c|c|}
\hline XSID : CODE & CRWS & FR\# & YMIN & YMAX & $\mathrm{HF}$ & $\mathrm{HO}$ & VHD & EGL & WSEL \\
\hline EXITX:XS & 90.01 & 1.00 & 79.79 & $110.65 *$ & $\star \star \star \star \star \star \star *$ & $\star \star \star \star \star ~$ & 2.59 & 92.65 & 90.07 \\
\hline FULLV : FV & 90.75 & 0.98 & 80.53 & 111.39 & 0.73 & 0.00 & 2.52 & 93.40 & 90.87 \\
\hline BRIDG : BR & 90.84 & 0.94 & 80.91 & 97.04 * & $\star \star \star \star \star \star \star *$ & $\star \star \star \star \star ~$ & 3.19 & 94.03 & 90.84 \\
\hline RDWAY : RG & 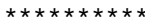 & 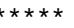 & 100.75 & 107.24 * & 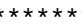 & $\star \star \star \star \star \star \star *$ & 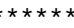 & $* * \star * * *$ & $\star \star \star \star \star \star *$ \\
\hline APPRO:AS & 91.04 & 0.64 & 81.03 & 101.75 & 0.56 & 0.76 & 1.52 & 95.34 & 93.82 \\
\hline
\end{tabular}

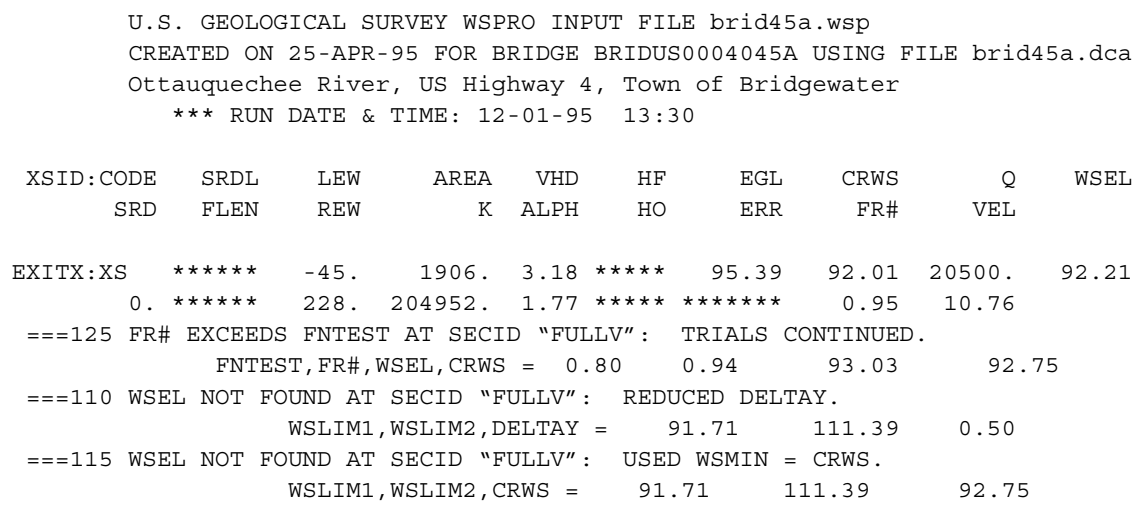

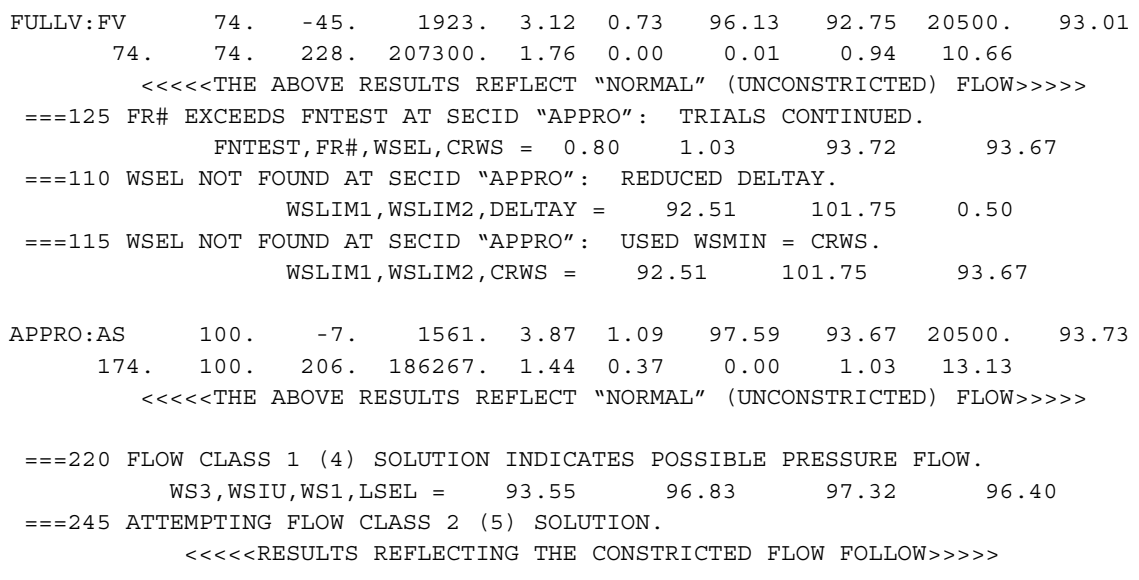

\begin{tabular}{|c|c|c|c|c|c|c|c|c|c|}
\hline XSID:CODE & CRWS & FR\# & YMIN & YMAX & $\mathrm{HF}$ & $\mathrm{HO}$ & VHD & EGL & WSEL \\
\hline EXITX:XS & 92.01 & 0.95 & 79.79 & $110.65 *$ & $\star \star \star \star \star * \star$ & $\star \star \star \star * *$ & 3.18 & 95.39 & 92.21 \\
\hline FULLV : FV & 92.75 & 0.94 & 80.53 & 111.39 & 0.73 & 0.00 & 3.12 & 96.13 & 93.01 \\
\hline BRIDG : BR & 93.49 & 0.73 & 80.91 & $97.04 *$ & $\star * * *$ & $\star \star * *$ & 2.56 & 99.39 & 96.83 \\
\hline RDWAY : RG & $\star \star \star \star \star * \star * *$ & $\star * \star * *$ & 100.75 & 107.24 & $0.09 *$ & 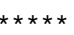 & 0.75 & 102.24 & 101.58 \\
\hline APPRO:AS & 93.67 & 0.40 & 81.03 & 101.75 & 0.27 & 0.63 & 0.75 & 102.33 & 101.58 \\
\hline
\end{tabular}


WSPRO OUTPUT FILE (continued)

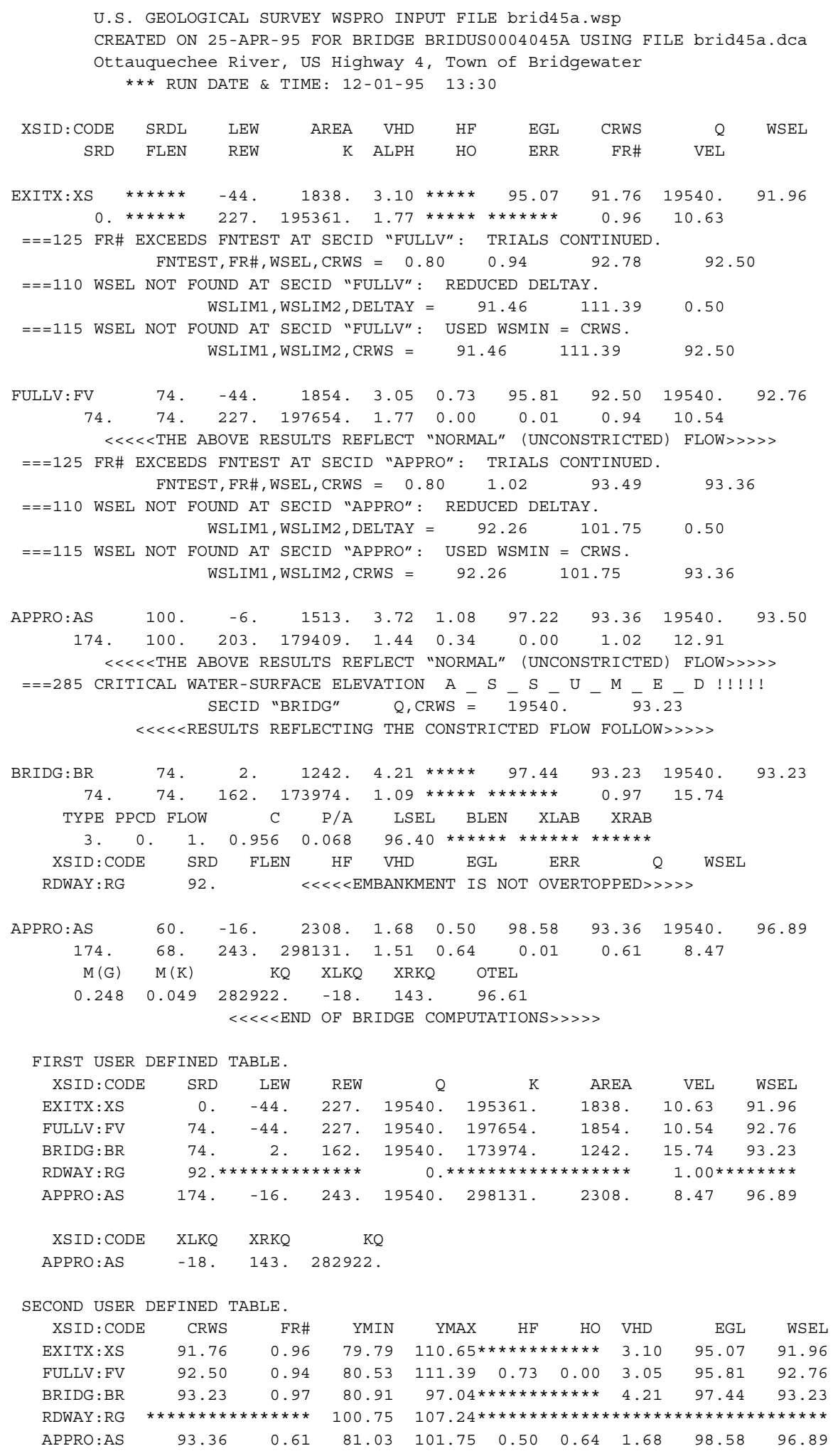




\section{APPENDIX C:}

\section{BED-MATERIAL PARTICAL-SIZE DISTRIBUTION}




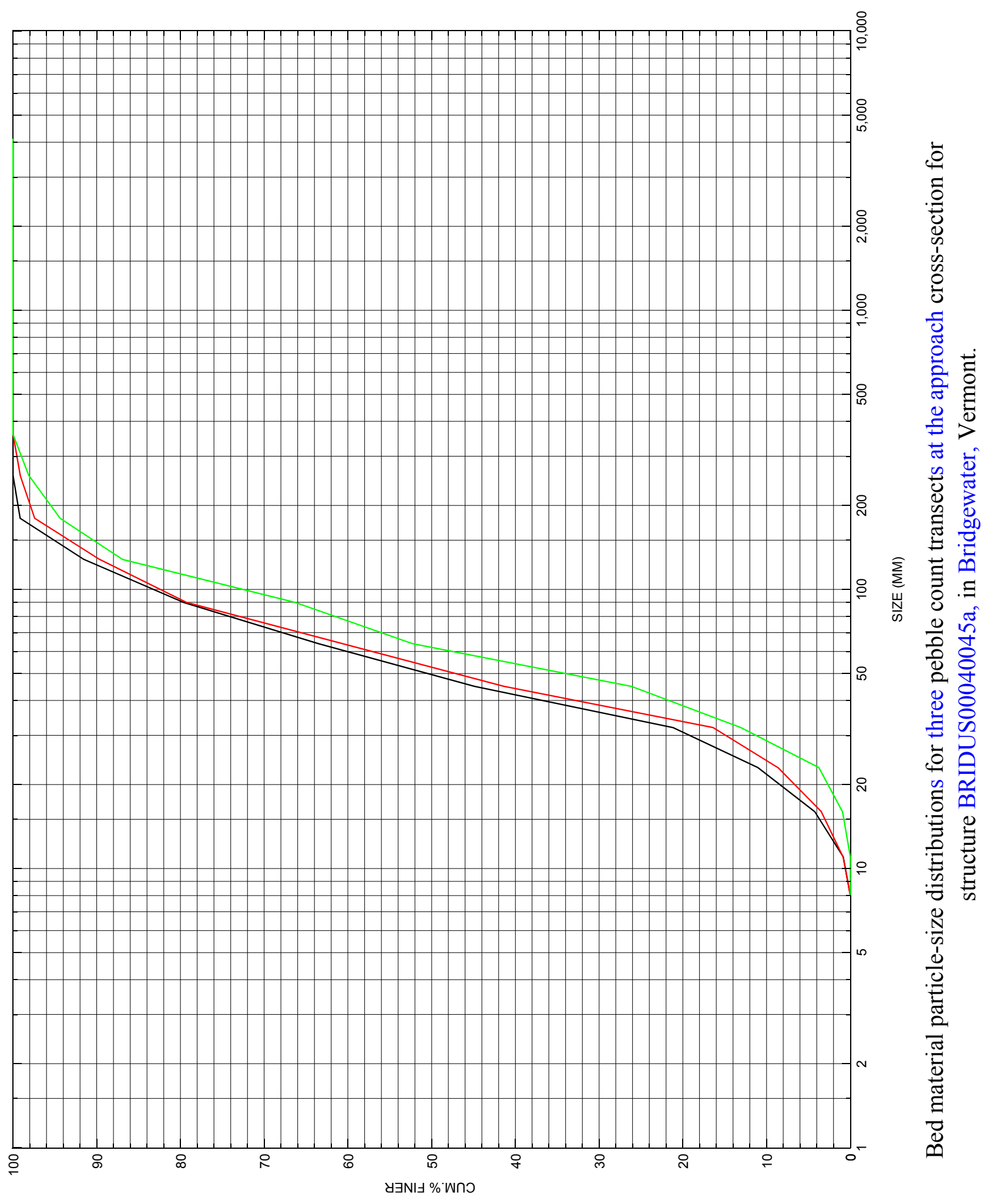




\section{APPENDIX D: \\ HISTORICAL DATA FORM}

